\title{
THE IMPACT OF QUALITY PERCEPTION AND VALUE PERCEPTION TOWARD PURCHASE INTENSITY (SURVEY COFFEE SHOP VISITORS IN PADANG CITY)
}

\author{
Agriqisthi ${ }^{1)}$ \\ Andalas University \\ agriqisthi@eb.unand.ac.id \\ Rasidah Nasrah') \\ Muhammad Yamin Solok University \\ Rasidahnasrah82@gmail.com
}

\begin{abstract}
The attraction of coffee is its unique taste and historical value, tradition, and life style. The phenomenon of coffee shops can not be separated from the habits or culture coffee drinking in community. This has encouraged business people, especially in Padang City to make coffee cafes a promising commodity for business opportunities. The purpose of this research is to find out; the impact of perceived quality on perceived value, and the effect of perceived value on repurchase intention. This research uses quantitative methods and uses SEM-PLS analysis to test research model. The observation unit in this study is customer Coffee Shops in Padang City as many as 120 respondents. In measuring variables using the Likert scale. The results found that the variable perceived quality significantly impact on perceived value, whereas perceived value significantly e on the repurchase intention.
\end{abstract}

Keyword : quality perceived, value perceived, and repurchase intentsity. 


\section{INTRODUCTION}

The popularity of coffee shops is inseparable from the 'coffee' habits that are built up in community. Society has made it as a necessity, there are even more in depth. The existence of a coffee shop can accommodate the needs and desires of consumers, such as the type of coffee offered, even the atmosphere of coffee shop.

As physical changes develop, coffee shops come in a modern atmosphere and provide more facilities, both in terms of menu choices, as well as facilities and infrastructure to support public facilities to attract visitors. Then coffee shop also offers coffee activities that are different from the previous coffee shop. Another difference in terms coffee price is much more expensive than ordinary coffee shops.

This has encouraged business actors, especially in Padang city to make coffee shops as a promising commodity to become a business opportunity. This phenomenon has led to emergence such various types of coffee shops in Padang city.

Based on the description above, can be seen in table 1 that presents data regarding the cafe development from 2014 to 2016 as follows:

Table 1: Development of Coffee Shops in Padang City in 2014 to 2016

\begin{tabular}{|c|c|c|}
\hline No & Year & Coffee shop total \\
\hline 1 & 2014 & 20 \\
\hline 2 & 2015 & 40 \\
\hline 3 & 2016 & 160 \\
\hline
\end{tabular}

Data source: Padang City Tourism Department

From table 1 it can be seen that the Coffee shop development in Padang City, the period in 2014 to 2016 experienced a significant development. This proves that coffee shops development in Padang city has increased. Seeing this phenomenon requires businesses to provide services and products that best suit customer needs in order to mastering the competition.

In addition to good taste, the menus availability and various menus offered are interest themselves for consumers. To maintain raw materials, there is always a need for upstream to downstream relations, this makes visitors feel the value of the overall quality of the products or services offered by coffee shop in Padang city. This is in line with the concept of quality perception conveyed by Wu and Chen (2014), that quality perception is the quality perceived by products consumers or services by relying on the whole set of basic and external product dimensions or service. It should be underlined, that the key to quality perception is consumers' assessment toward advantages and attributes inherent in the product.

The products offered by coffee shops in Padang City cannot be separated from the value felt by costumers. Values in this context are understood as consumers' conclusions about products that are often not related to prices (Zehir et al, 2014). It is simply understood that the use product value is interpreted as a perception about what is received by consumers from what they have given. This then becomes consumers consideration in making decisions to choose certain products. A significant factor in 
playing a role in decision making process is called value perception (Gursoy et al., 2014).

In a studies series conducted by Pike and Bianchi, 2013; Milfelner, 2009; Haque \& Khan, 2013; Milfelner, 2009, can be drawn a common thread that perceived value is directly related to customer satisfaction and loyalty. Thus, as an important element in marketing and as a step to remain competitive, businesses are obliged to increase the perceived products value that offered to consumers by increasing benefits received by consumers beyond the offer. The ultimate goal is to create and maintain long-term relationships to benefit from customer loyalty. Loyalty will be marked by a repeat purchase made by consumers, and also recommend to others.

\section{LITERATURE REVIEW}

\section{A. Quality Perception}

In simple terms, the perception of quality can be defined as a consumer's assessment of the overall product superiority or superiority. In a deeper definition of quality perception is "the customers perception of the overall quality or superiority of a product or service with respect to its intended purpose, relative to alternatives" Aaker (2009). So, it can be understood that quality perception is a matter of consumer quality perception and excellence of a product or service. The key is consumer perception. It is important to note that product quality is an important resource for companies to be able to compete with other products.

Quality perception can also be used as a brand extension tool. A brand with a strong quality perception will be able to expand further and will have a greater success chance than a weak brand (Susanto and Wijanarko, 2004). In addition, the perception of quality also has an important role in building a brand. The quality that is owned by a brand, can be used as a reason when consumers choose the desired product, it will indirectly affect consumers in deciding which brands to buy.

\section{B. Value Perception}

Perception is the process used by an individual to select, organize, and interpret information inputs to create a meaningful picture of the world (Kotler and Keller, 2012). The term "value" has its basis in the economic literature. From an economic point of view, value is the benefit minus the costs that both buyers and sellers get from a product. An exchange will not occur unless there are benefits for both parties, where both parties must feel that consumers get more than what consumers give in transaction activities (Wu and Chen (2014)). Value perception views quality in value terms and price. By considering performance and price, quality is defined as affordable excellence. Quality in this case is relative so that the most valuable products are the most appropriate goods and services purchased.

According to Shiffman and Kanuk (2008) perceived value is measured based on monetary and non-monetary costs combined with quality perception. Value perception is a significant factor that plays a role in the decision making process (Gursoy et al., 
2014), and perceived value is one of important elements in marketing to gain competitive advantage (Haque \& Khan, 2013).

\section{Repurchase Intensity}

If the individual is interested in something this is because the object is useful to meet their needs. A person's tendency to give attention when accompanied by feelings of like or often referred to as interests (Rustan, 2008). Ratnawati (2002) suggests that interest is a tendency to behave oriented towards certain objects, activities and experiences, further explaining that the intensity of a person's tendencies differs from the others, perhaps greater intensity or smaller depending on each person.

The intensity of repurchase is defined as individual consideration related to the repurchase a particular product or service, (Hellier et al., 2003) and the main reason is in the experience after shopping. Companies instead of attracting new customers can retain previous customers at less cost (Zeithaml, 1996).

\section{Conceptual Framework}

The conceptual framework developed in this study is expected to be able to describe the research that will be conducted by researchers as a whole, namely to determine the impact of perceived quality and perceived value toward repurchases intensity on Coffee shop in Padang city. In this section, based on the theory that has been studied, a conceptual thinking model will be proposed which has become an empirical research model and serves as a guideline in conducting research, which will further demonstrate the effect of perceived quality and perceived value on the intensity of repurchases described in the following frame of mind:

Figure 1: Conceptual Framework

\begin{tabular}{|c|c|c|c|c|}
\hline $\begin{array}{l}\text { Quality } \\
\text { perception }\end{array}$ & $\mathrm{H} 1$ & $\begin{array}{l}\text { Value } \\
\text { perception }\end{array}$ & $\mathrm{H} 2$ & $\begin{array}{c}\text { repurchases } \\
\text { intensity }\end{array}$ \\
\hline
\end{tabular}

Data source: Related research

Then found the hypothesis:

H1: Allegedly perceived quality has a significant impact on perceived value at Coffe shop in Padang city

H2: Allegedly the perceived value has a significant impact on the repurchases intensity at Coffe shop in Padang city

\section{RESEARCH METHODS}

\section{A. Research Type}

This research uses explanatory research that is research used to find out whether or not the influence of a variable in a particular situation (Sekaran, 2006). This research uses quantitative methods. The data collection apply by distributing questionnaires. This study uses a cross-sectional time horizon. The observation unit in this study is the coffee shop customers in Padang City.

\section{B. Population, Samples and Sampling Techniques}

This study uses a type of sampling in nonprobability sampling form with purposive sampling technique. Purposive sampling technique is a technique for 
determining samples based on previously known population characteristics (Sekaran, 2006). Therefore, the criteria chosen as a sample in this study are consumers who visit the Coffee Shop in Padang city with an age above 17 years, because consumers are considered to be able to fill out the questionnaire properly and correctly. The number of samples used in this study were 120 respondents.

\section{Definition of Variable Operations}

Variables are anything that can distinguish or bring variation in value (Sekaran, 2011). This study consists of three variables, namely repurchase intensity as the dependent variable $(\mathrm{Y})$, perceived quality $(\mathrm{X} 1)$ and perceived value $(\mathrm{X} 2)$ as independent variables. The operational definitions of each variable are as follows:

Table 2: Operationalization of Variables

\begin{tabular}{|c|c|c|}
\hline Variable & Defenition & Indicator \\
\hline $\begin{array}{l}\text { Quality } \\
\text { perception } \\
\text { (Zeithaml, } \\
\text { 1988) }\end{array}$ & $\begin{array}{l}\text { As an overall consumer } \\
\text { assessment to product } \\
\text { attributes }\end{array}$ & $\begin{array}{l}\text { 1. Product characteristics } \\
\text { 2. Compliance with specifications } \\
\text { 3. Reliability } \\
\text { 4. Endurance } \\
\text { 5. Service } \\
\text { 6. Final results }\end{array}$ \\
\hline $\begin{array}{l}\text { Value } \\
\text { perception } \\
\text { (Wu and } \\
\text { Chen, } \\
2014)\end{array}$ & $\begin{array}{l}\text { Overall consumer } \\
\text { assessment of the uses of a } \\
\text { product for what is received } \\
\text { and given by the product. }\end{array}$ & $\begin{array}{l}\text { 1. Products provide more value } \\
\text { 2. The money given to buy a product is } \\
\text { proportional to the value. } \\
\text { 3. The product has high usability } \\
\text { 4. Products as you wish. } \\
\text { 5. Products provide more benefits than } \\
\text { losses. }\end{array}$ \\
\hline $\begin{array}{l}\text { Repurchase } \\
\text { intensity of } \\
\text { (Nida, } \\
\text { 2008, } \\
\text { Minanti } \\
(2014), \\
\text { Patty, 2015) }\end{array}$ & $\begin{array}{l}\text { The desire of customers to } \\
\text { make repeat purchases for } \\
\text { the future. }\end{array}$ & $\begin{array}{l}\text { 1. Plan to buy the same product. } \\
\text { 2. Plan to try other products. } \\
\text { 3. Plan to buy more of the same product or } \\
\text { other products. }\end{array}$ \\
\hline
\end{tabular}

Data sources: Zeithaml (1988), Wu and Chen (2014), Minanti (2014), and Patty (2015)

\section{Data Processing Techniques}

This study uses a data analysis method used SmartPLS 2 software that is run on computer media. PLS is a variance-based structural equation analysis that can simultaneously test measurement models as well as structural model testing (Hair, et.al, 2010). 
In accordance with the hypotheses that have been formulated, in this study inferential statistical data analysis was measured used SmartPLS 2.0 software starting from the measurement of the model (outer model), structure model (inner model) and hypothesis testing (Hair, et.al, 2010).

PLS uses a three-stage iteration process and each iteration stage produces an estimate. The first stage, produces a weight estimate that is used to create latent score variables. The second step produces estimates for the inner model and outer model and reflects the path estimate (path estimate) that connects latent variable and between latent variable and its indicator (loading). The third stage produces estimated means and location parameters (regression constant values) for indicators and latent variables (Ghozali, Imam, 2014).

\section{Outer Model}

The construct validity test in PLS is carried out through convergent validity, discriminant validity and average variance extracted (AVE) tests. Reliability test is used to measure the measuring consistency instruments in measuring concepts or can also be used to measure the respondents consistency in answering instruments. Instruments are said to be reliable if a person's answer to a statement is consistent or stable over time. Reliability testing in PLS can use the composite reliability method and Cronbach's alpha (Hair, et.al, 2010).

\section{Inner model}

Inner models (inner relations, structural models, and substantive theory) describe the relationship between latent variables based on substantive theory. The structural model is evaluated by using the R-square for the dependent construct, the Stone-Geisser $Q$-square test for predictive relevance, and the $t$ test and structural significance path coefficient parameters (Hair, et.al, 2010).

\section{Hypothesis test}

The significance hypothesis measure support can be used to compare $t$-table and $\mathrm{t}$-statistic values. The hypothesis is supported or accepted if $\mathrm{t}$-statistic is higher than $\mathrm{t}$ table value or it can also compare $p$-value with a value used. The t-table value for onetailed hypothesis with a 95 percent confidence level $(a=0.05)$ is 1.96. Supporting hypothesis in the study occurs when t-statistic value $>1.96$ or $p$-value $<a=0.05$. PLS analysis used in this study was conducted using the SmartPLS 2 program which was run on computer media (Ghozali, Imam, 2014).

\section{RESULTS AND DISCUSSION}

\section{A. Outer Model}

\section{Outer Loading}

The research construct can be seen from Figure 1. To see convergent validity, you can see table 2 .

Figure 2: Figure Construction Research 


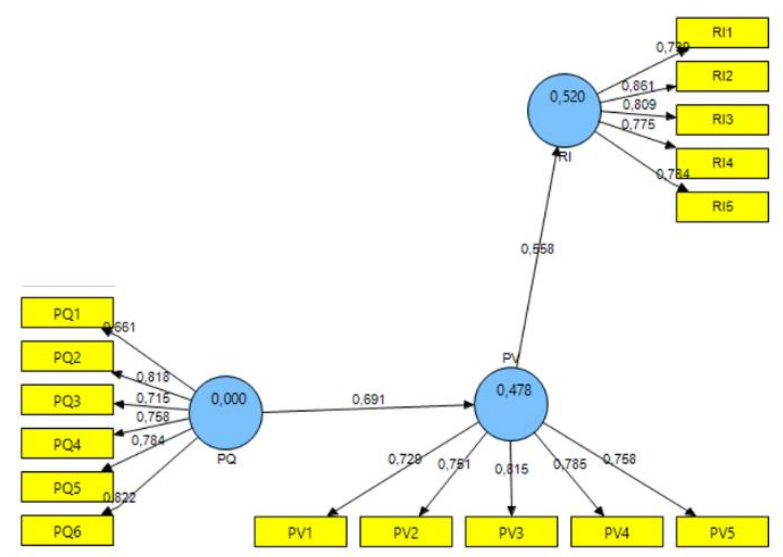

Data source: Primary data processed

Table 2: Outer Loading Results

\begin{tabular}{lll}
\hline Indicator & $\begin{array}{l}\text { Loading } \\
\text { Factor }\end{array}$ & $\begin{array}{l}\text { Validity } \\
\text { test }\end{array}$ \\
\hline
\end{tabular}

Quality perception (X1)

X1.1 0,660889 Valid

X1.2 $\quad 0,817575 \quad$ Valid

X1.3 $\quad 0,714641 \quad$ Valid

X1.4 $\quad 0,757676 \quad$ Valid

X1.5 $\quad 0,783624 \quad$ Valid

X1.6 $\quad 0,821777 \quad$ Valid

Value perception $(\mathrm{X} 2)$

X2.1 $\quad 0,728610 \quad$ Valid

X2.2 $\quad 0,751434 \quad$ Valid

X2.3 $\quad 0,814980 \quad$ Valid

X2.4 $\quad 0,785446 \quad$ Valid

X2.5 0,757554 Valid

Repurchase intensity $(\mathrm{Y})$

Y1.1 $\quad 0,738221 \quad$ Valid

Y1.2 0,860976 Valid

Y1.3 0,810622 Valid

Y1.4 0,774209 Valid

Y1.5 0,783585 Valid

Data source: Primary data processed

From the table above it is known that each indicator has an outer loading value above 0.6. This shown that there is a good convergent validity value, indicator can explained the variable.

\section{AVE}

Table 3: Average Variance Extract

Variable AVE




\begin{tabular}{ll}
\hline Quality & 0,579895 \\
perception & 0,590106 \\
Value perception & Repurchase \\
intensity & 0,631353 \\
\hline Data source: Primary data processed
\end{tabular}

As for the AVE value has requirements where the AVE value is above 0.5

Composite Reliability

Table 4: Composite Reliability

\begin{tabular}{ll}
\hline Variable & $\begin{array}{l}\text { Composite } \\
\text { Reliability }\end{array}$ \\
\hline Quality & 0,891723 \\
perception & 0,877862 \\
$\begin{array}{l}\text { Value perception } \\
\text { Repurchase }\end{array}$ & 0,895182 \\
intensity & \\
\hline
\end{tabular}

Data source: Primary data processed

The reliability reliability test has fulfilled the requirements where the composite reliability value is more than 0.7

Cronbachs Alpha

Table 5: Cronbachs Alpha

\begin{tabular}{ll}
\hline Variable & Cronbachs Alpha \\
\hline Quality & 0,853261 \\
perception & 0,825925 \\
$\begin{array}{l}\text { Value perception } \\
\text { Repurchase } \\
\text { intensity }\end{array}$ & 0,853321 \\
\hline
\end{tabular}

Data source: Primary data processed

Table 5. above shown that all values have passed the coefficient 0.7 , and have a high composite reliability value. Therefore, the indicators used in this research variable are said to be reliable.

\section{B. Inner Model}

\section{R-Square}

Table 6: R-Square

\begin{tabular}{ll}
\hline Variable & R-Square \\
\hline $\begin{array}{l}\text { Perception value } \\
\text { Intensitas }\end{array}$ & 0,478 \\
$\begin{array}{l}\text { Repurchase } \\
\text { intensity }\end{array}$ & 0,528 \\
\hline
\end{tabular}

Data source: Primary data processed 
Based on table 6 . it can be seen that the variable perceived quality can affect perception value is $47.8 \%$, while remaining $52.2 \%$ is influenced by other variables not explained in this study. However, the intensity of repurchase can be influenced by quality perceptio and perceived value is $52.8 \%$ and remaining $47.2 \%$ is explained by other variables not present in this research.

\section{Hypothesis Testing}

Table 7: Hypothesis Testing Results

\begin{tabular}{lll}
\hline Relationship & T Statistics $(\mid \mathrm{O} /$ STERR $\mid)$ & $\begin{array}{l}\text { Sig. Level } \\
\text { Quality perception-> Perception value }\end{array}$ \\
22,686205 & Significant \\
Perception value-> Repurchase intensity & 8,694113 & Signicant
\end{tabular}

Data source: Primary data processed

Based on table 7 it can be seen that the quality perception also has significant impact (22.6862> 1.96) on perception value, so that H2 is accepted. For H3 accepted because the perceived value has a significant effect $(8.6941>1.96)$ on the repurchase intensity.

\section{Discussion}

\section{Effect of Quality Perception on Value Perception}

Quality perception has a significant effect on perceived value, the results show a similarity with previous research conducted by Wu and Chen (2014) which states that there is a negative influence between perceived quality on perceived value. The equation between the study results with proposed hypothesis statement, means that Hypothesis II is accepted. This shows that the greater quality perception by consumers it will have a positive and significant influence on perceived value of the Lush.

\section{Effect of Value Perception on Repurchase Intensity}

Based on the hypothesis test shows that the perception of value has a positive and significant influence on repurchase intensity, therefore hypothesis III is accepted. These results indicate that the greater consumer toward perception value, the greater the repurchases intensity possibility. This is reinforced by study results of $\mathrm{Wu}$ and Chen (2014) adding that before perception value will trigger a repeat purchase, it will lead to purchase intention.

\section{CONCLUSION}

\section{A. Conclusion}

Based on the results of the analysis and discussion in the previous chapter, the following conclusions can be drawn:

1) Quality perception has a significant effect on perceived value at Coffee Shops in Padang city

2) Perception value has a significant effect on repurchase intensity at Coffee Shops in Padang city 


\section{B. Research Implications}

Based on the study results, the input for strategies that can be applied by the Coffee Shop in Padang city is in order to maintain service quality. In addition coffee shop can innovate various products so that consumers do not get bored and still maintain the current products type and the concept must be maintained because consumers are comfortable with the concept.

\section{Research Limitations}

This research is still far away from perfection, therefore in the future it will be more developed by further researchers, for example, perhaps it may be necessary to add other variables related to solving the problem of repurchase intensity at companies, especially those engaged in the coffee shop business. In addition it is necessary to consider increasing research sample so that research will be more optimal, or need to do the expansion of research objects that are not only in one company so that they can compare problems that occur in one company with another company.

\section{Suggestions}

\section{For Coffee Shop Managers in the city of Padang}

Based on the research results and conclusions obtained, several suggestions that can be considered by coffee shops in Padang to be taken regarding future policies in order to solve the problem of repurchase intensity are as follows:

\section{Perceived Quality}

For the coffee shop business in Padang city, it is very important to be consistent with quality so that consumers continue to feel satisfied and loyal. Product quality must be maintained

\section{Perceived Value}

Coffee shops must strive to improve consumer satisfaction today. In addition, coffee shops must maintain relationships with consumers, especially those who belong to the Hoarder.

\section{For Future Research}

The suggestions for future research are as follows:

This study only analyzes perceived aspects quality and perceived value of repurchase intensity so it is recommended for further research to be able to add other variables that can explain more deeply about repurchase intensity. Such as, cultural perceptions and many other variables that can be used as a reference to determine its effect on repurchase intensity.

\section{REFERENCE}

Aaker, David A. (2009). Managing Brand Equity: Capitalizing on the Value of a Brand Name. New York: The Free Press

Aaker, David A. (2011). Building Strong Brands. New York: Simon and Schuster. 
Gursoy, D., Chen,J., \& Chi, C. G. 2014. Theoretical Examination of Destination Loyalty Formation. International Journal of Contemporary Hospitality Management, Vol. 26, No. 5

Haque, A \& Khan, H.A (2013). Factors influencing of tourist loyalty: A Study on Tourist Destinations in Malaysia. Proceedings of 3rd Asia-Pacific Business Research Conference 25-ISBN: 978-1-922069-19-1.

Hellier, P. K., G. M. Geursen, R. A. Carr \& J. A. Rickard. 2003. “Customer Repurchase Intention: A general structural equation model". European Journal of Marketing, Vol. 37, No. 11/12, pp.1762-1800.

I. Ghozali, Aplikasi Analisi Multivariate dengan menggunakan SPSS. 2014.

J. F. Hair, W. C. Black, B. J. Babin, and R. E. Anderson, Multivariate Data Analysis 7ed. 2010.

Kotler, Philip and Keller, Kevin Lane. (2012) Marketing Management, 14th Edition. New Jersey: Prentice Hall.

Milfelner, B., Snoj, B., \& Korda, A. P.(2009). Measurement of Perceived Quality, Perceived Value, Image, and Satisfaction Interrelations of Hotel Services: Comparison of Tourists from Slovenia and Italy.pp 605-624.

Pike S., and Bianchi C. (2013). Destination Brand Equity for Australia: Testing a Model of CBBE in Short-Haul and Long-Haul Markets. Journal of Hospitality and Tourism Research. Exchanges, Vol. 6, No.2.

Ratnawati. (2002). Mengukur Kepuasan Masyarakat terhadap Pelayanan Pendidikan. Jurnal Pendidikan No. 043. Juli 2002

Rosandi, Patty Anugrah. (2015). Pengaruh Persepsi Konsumen Tentang Penerapan Peraturan Pemerintah (PP) No 109 Tahun 2012 Mengenai Tembakau Terhadap Repurchase Intention Konsumen Rokok Di Indonesia Tahun 2014.

Rustan, S. (2008). Layout, Dasar dan Penerapannya. Jakarta :Gramedia Pustaka Utama.

Safria, Minanti Haut. (2014). Pengaruh Bauran Pemasaran Yang Berbasis Konsep Green Marketing Terhadap Minat Membeli Ulang Produk Tupperware (StudiKasus di Wilayah Kecamatan Sumbersari, Jember).

Schiffman, Leon dan Kanuk, Leslie Lazar .(2008). Perilaku Konsumen. Edisi Ketujuh. Jakarta: Indeks. 
U. Sekaran, Research methods for business metedologi penelitian untuk bisnis. 2015.

$\mathrm{Wu}$, Shwu-Ing and Chen, Yen-Jou. (2014). The Impact of Green Marketing and Perceived Innovation on Purchase Intention for Green Products. International Journal of Marketing Studies: Vol. 6, No. 5.

Zehir, Cemal., Sehitoglu, Yasin., Narcikara, Elif., and Zehir, Songul. (2014). E-S Quality, Perceived Value and Loyalty Intentions Relationships in Internet Retailers. Procedia Social and Behavioral Sciences 150.

Zeitmal, Valarie A., Berry, Leonard L., And Parasuraman, A. (1996) The Behaviorial Consequences of Service Quality. Journal of Marketing, Vol. 60, No. 2 